\title{
PENINGKATAN AKTIVITAS BELAJAR SISWA MELALUI PENERAPAN METODE "JUMPING TASK" PADA PEMBELAJARAN GEOGRAFI
}

\author{
NOFRION 1 \\ 1Dosen Jurusan Geografi Universitas Negeri Padang \\ Jl. Prof. Dr. Hamka Air Tawar Padang, Sumatera Barat \\ Email : dion_geografi@yahoo.com
}

\begin{abstract}
Abstrak
Tujuan penelitian ini adalah untuk meningkatkan aktivitas belajar siswa dalam pembelajaran Geografi melalui penerapan metode "Jumping Task". Metode "Jumping Task" adalah metode pembelajaran yang ditandai dengan pemberian soal atau tugas yang menantang kepada siswa sehingga diharapkan siswa akan bekerja sama dalam mengerjakan soal/tugas tersebut melalui dialog, interaksi dan kolaborasi yang dikelola secara efektif dan efisien oleh guru. Aktivitas belajar yang diamati dalam penelitian ini adalah aktivitas belajar individu, aktivitas belajar berpasangan, aktivitas belajar dalam kelompok dan aktivitas belajar klasikal. Penelitian tindakan kelas ini dilaksanakan sebanyak tiga kali pembelajaran/siklus di di kelas X SMA Islam Al Istiqamah, Pasaman Barat. Hasil penelitian memperlihatkan bahwa penerapan metode "jumping task" berhasil meningkatkan aktivitas belajar siswa dengan tingkat capaian di atas $80 \%$ pada semua jenis aktivitas belajar yang diobservasi.
\end{abstract}

Kata Kunci : Aktivitas Belajar, Pembelajaran Geografi, Metode Jumping Task

\begin{abstract}
The objectives of this research is to improve the students learning activities in geography learning through the implementation of Jumping Task Method. Jumping Task Method is a learning method that is characterized by the provision of a matter or a challenging task to the students so that the students will be expected to cooperate in work on the problems / tasks through dialogue, interaction and collaboration are managed effectively and efficiently by the teacher. Learning activity observed in this study is the individual learning activities, and learning activities in pairs, group learning activities and activities of classical learning. This classroom action research conducted three times learning / cycle in class X SMA Islam Al Istiqamah, Pasaman Barat. The results showed that the implementation of the jumping task method successfully improving student learning activities with performance levels above $80 \%$ in all types of learning activities were observed.
\end{abstract}

Keywords : Learning Activitiy, Geography Learning, Jumping Task Method

\section{PENDAHULUAN}

Dalam Undang-undang Nomor 20 tahun 2003 tentang Sistem Pendidikan Nasional Pasal 1 Ayat 20 dinyatakan bahwa pembelajaran adalah proses interaksi peserta didik dengan pendidik dan sumber belajar pada suatu lingkungan belajar. Definisi tersebut menjelaskan bahwa keberadaan pendidik, peserta didik, adanya interaksi antara pendidik dengan peserta didik, dan interaksi pendidik dan peserta didik dengan sumber belajar dalam suatu lingkungan belajar adalah suatu keharusan. Secara jelas juga dituliskan dalam Permendikbud nomor 22 tahun 2016 tentang Standar Proses Pendidikan Dasar dan Menengah bahwa proses pembelajaran pada satuan pendidikan diselenggarakan secara interaktif, 
inspiratif, menyenangkan, menantang, memotivasi pesertadidik untuk berpartisipasi aktif, serta memberikan ruang yang cukup bagi prakarsa, kreativitas, dan kemandirian sesuai dengan bakat, minat, dan perkembangan fisik serta psikologis peserta didik. Sehubungan dengan hal tersebut, paradigma pembelajaran abad 21 ditandai oleh beberapa hal diantaranya adalah; 1) core subject, 2) globally aware, 3) creative, 4) innovative, 5) collaborative, 6) communicative, 7) critical thinking, 8) ethic and humanistic.

Dalam konteks ini dan dalam perspektif Kurikulum 2013, peran guru sudah bergeser dari sumber belajar utama menjadi salah satu sumber belajar, dari pemberi tahu menjadi pemicu anak untuk mencari tahu serta dari "teacher dominated learning" menjadi fasilitator dan "learning observatory". Namun demikian, berjalannya pembelajaran tetap berada dalam kendali dan pengelolaan guru. Tugas utama guru adalah menumbuhkan kesadaran dan kepedulian belajar di kalangan peserta didik serta merangsang peserta didik untuk belajar optimal untuk mendapatkan hasil yang optimal pula. Kesadaran dan kepedulian peserta didik dalam belajar akan terlihat dari aktivitas belajar yang dilakukan selama pembelajaran.

Berdasarkan wawancara dengan Bapak Mulyadi, S. Pd (Guru Geografi dan Ketua MGMP ) tanggal 7 Maret 2016 terungkap bahwa permasalahan yang sering dihadapi guru di kelas adalah masih rendahnya aktivitas belajar siswa pada mata pelajaran geografi. Siswa lebih cenderung menjadi pembelajar yang pasif dimana sering menempatkan diri sebagai penerima informasi semata dan sangat sulit untuk terlibat sebagai pembelajar aktif yang ditandai dengan kemauan yang tinggi untuk berfikir dan memecahkan berbagai masalah dalam pembelajaran. Kondisi ini juga disampaikan oleh Bapak Dedi Nafrizal dan Ibu Iftitah Rahmi (Guru Geografi) yang menyatakan bahwa, berbagai model dan metode yang sudah dilakukan di dalam pembelajaran belum mampu membuat pembelajaran menjadi hidup dan menyenangkan serta masih sulit membangkitkan semangat siswa untuk terlibat aktif selama pembelajaran berlangsung.

Berdasarkan permasalahan di atas, perlu dilakukan suatu upaya nyata untuk meningkatkan aktivitas belajar siswa selama pembelajaran berlangsung. Aktivitas belajar yang tinggi diharapkan mampu meningkatkan pemahaman siswa terhadap materi pelajaran (aspek kognitif dan keterampilan), serta pengelolaan dan metode pembelajaran yang baik juga diharapkan mampu mengembangkan aspek-aspek sikap spiritual dan sosial di kalangan siswa (nurturant effect). Sehingga, pembelajaran yang dilaksanakan tidak hanya "cognitive oriented" tapi juga menumbuhkembangkan aspek keterampilan dan sikap secara komprehensif sesuai dengan paradigma pembelajaran dalam Kurikulum 2013.

Salah satu upaya yang bisa dilakukan adalah dengan menerapkan metode pembelajaran "Jumping Task". Metode "Jumping Task" adalah pemberian soal/tugas yang menantang/berada di atas tingkatan tuntatan kurikulum. Praktik ini sudah lama dilaksanakan di berbagai negara maju seperti Jepang. Dalam kegiatan penelitian dan observasi pembelajaran yang penulis lakukan selama di Jepang tahun 2014 dalam program Short-Term Training of Lesson Study for Institution Teacher Training and Educational Personnels (STOLS for ITTEP) dimana penulis melakukan observasi pembelajaran mulai dari Sekolah Dasar sampai Perguruan Tinggi di Jepang, terlihat bahwa guru-guru di Jepang sukses meningkatkan aktivitas belajar siswa di kelas melalui pemberian soal/tugas dengan kategori "Jumping Task". Di Jepang sendiri, mereka tidak memberi nama praktik ini sebagai suatu model atau metode pembelajaran namun 


\section{ge}

sudah menjadi praktik umum di kalangan guru terutama mereka yang sudah menerapkan reformasi sekolah yang disebut "Lesson Study". Konsep ini yang disampaikan oleh Manabu Sato yang disebut dengan reformasi kelas dengan fokus pada aktivitas belajar berupa terciptanya dialog, interaksi dan kolaborasi di antara peserta didik (Sato, 2013:21-34).

Keunggulan metode "jumping task" ini adalah mampu menciptakan aktivitas belajar di kalangan siswa seperti terjadinya dialog, interaksi dan kolaborasi yang efektif. Untuk kepentingan penelitian ini, penulis membuat penataan pembelajaran dengan merancang polapola dialog dan kolaborasi antara peserta didik yang terdiri dari "individual activity", "activity in pair", activity in group" dan classical activity. Dalam praktiknya, penulis mengakomodasi konsep Zone of Proximal Development/ZPD oleh Vygotsky yang menjelaskan bahwa seorang anak dapat melakukan dan memahami lebih banyak hal jika mereka mendapat bantuan dan berinteraksi dengan orang lain, termasuk teman sebayanya. Untuk memaksimalkan perkembangan, siswa seharusnya bekerja dengan teman yang lebih terampil yang dapat memimpin secara sistematis dalam memecahkan masalah yang lebih kompleks.

Berdasarkan rasionalitas di atas, maka penulis bersama dengan guru Geografi di Pasaman Barat melaksanakan suatu penelitian tindakan kelas yang berjudul "Peningkatan Aktivitas Belajar Siswa melalui Penerapan Metode "Jumping Task" pada Pembelajaran Geografi. Tujuan penelitian ini adalah untuk meningkatkan aktivitas belajar siswa yang meliputi aktivitas individu, aktivitas berpasangan, aktivitas dalam kelompok dan aktivitas klasikal yang tampak melalui dialog, interaksi dan kolaborasi antar peserta didik dalam mengerjakan tugas/soal yang diberikan. Manfaat penelitian ini adalah terciptanya kepedulian (caring community) di kalangan peserta didik serta tumbuhnya semangat untuk selalu berupaya meningkatkan kualitas pembelajaran di kalangan guru.

\section{METODE PENELITIAN}

Jenis penelitian ini adalah penelitian tindakan kelas (classroom action research) yang dikembangkan oleh Kemmis dan Mc.Taggart (1993) yaitu melalui siklus yang terdiri dari planning (perencanaan), acting (pelaksanan), observing (observasi), reflecting (refleksi). Dalam penelitian ini juga diintegrasikan pola-pola pembelajaran berbasis Lesson Study for Learning Community (LSLC). Namun, dalam pelaksanaannya penelitian ini bisa juga dikategorikan sebagai penelitian tindakan kelas non-PTK karena yang bertindak sebagai pelaksana tidak hanya guru tapi juga peneliti.

Sesuai dengan format Penelitian Tindakan Kelas, penelitian ini dilaksanakan dengan sistim siklus. Masing-masing siklus dilaksanakan 3 kali pertemuan, sampai mencapai sasaran yang dituju. Penelitian ini juga dilakukan secara kolaboratif, kooperatif dan observasi yang melibat-kan tim peneliti dan guru-guru sebagai observer pembelajaran. Penelitian ini dilakukan dalam 4 langkah atau tahap pada tiap-tiap siklus, yaitu:

a. Perencanaan (planning).

Perencanaan tindakan berupa penyusunan rencana penelitian dalam proses pembelajaran pada pembelajaran Geografi di kelas X SMA Islam Al Istiqamah yang meliputi: 1) Mempersiapkan perangkat pembelajaran berupa Rencana Program Pembelajaran (RPP) yang mengacu pada silabus dan penilaian pada mata pelajaran Geografi dikelas X semester I, 2) Mendiskusikan rencana pembelajaran dengan guru mata pelajaran sejenis maupun sejawat sebaik-baik anggota kolaborasi, 3) Merancang instrumen penelitian untuk menyusun format observasi aktifitas 
belajar siswa bersama guru mitra, 4) Membicarakan dengan guru mitra tentang format observasi

b. Pelaksanaan Tindakan (acting). Pada tiap-tiap siklus yang dilakukan mengikuti tahapan-tahapan sebagai berikut: 1) Guru memulai pembelajaran dengan pendahuluan dan menjelaskan tujuan pembelajaran yang akan dicapai, 2) Melakukan tes awal (tergantung kondisi) untuk mengukur penguasaan siswa tentang materi yang akan diajarkan, 3) Membagi siswa ke dalam kelompok-kelompok kecil yang beranggotakan 4 orang secara heterogen dan memberikan bahan bacaan untuk dipahami oleh anggota kelompoknya, 4) Menjelaskan kepada siswa tentang prosedur pembelajaran dengan metode "Jumping Task" yang akan dilaksanakan, 5) Guru menampilkan video yang berhubungan dengan pembelajaran serta menjelaskan konsep materi secara ringkas, selanjutnya siswa mengamati video yang ditampilkan, membaca dan memahami materi untuk bahan diskusi dengan anggota kelompoknya, 6) melakukan diskusi antar kelompok dalam kelas, guru mengarahkan sedangkan teman anggota kolaborator mengamati aktifitas siswa dan mencatanya pada lembar observasi, 7) Guru memberikan tugas/kegiatan/soal Jumping Task. 8) Siswa dalam pengawasan guru membahas soal/tugas yang telah diberikan secara tuntas dan 9) siswa bersama guru melakukan refleksi pembelajaran.

c. Pengamatan (Observasi). Pada tahap ini peneliti dan para observer mencatat aktifitas siswa selama proses pembelajaran berlangsung pada lembaran observasi yang telah disediakan. Pendokumentasian aktivitas belajar siswa dapat dilakukan dengan foto, video dan sebagainya. Teknisnya tersendiri.

d. Renungan (refleksi). Pada tahap ini peneliti melakukan pengolahan data yang didasarkan pada hasil pengamatan pada tahap observasi. Dalam tahap refleksi ini masingmasing observer dapat menampilkan temuan-temuan khusus terkait aktivitas belajar atau kasus yang ditemukan yang layak untuk dijadikan pembahasan dalam refleksi. Hal ini bertujuan untuk mengatasi permasalahan yang dihadapi siswa serta menentukan tingkat keberhasilan yang telah dicapai pada tiap-tiap pertemuan pada masing-masing siklus.

Penelitian ini dilaksanakan di SMA Al Istiqamah, Kabupaten Pasaman Barat yang dilaksanakan sebanyak tiga kali siklus yaitu siklus 1 tanggal 26 September 2016, siklus 2 tanggal 10 Oktober 2016 dan siklus 3 tanggal 17 Oktober 2016. Subjek penelitian ini adalah siswa kelas X SMA Al Istiqamah di Kabupaten Pasaman Barat yaitu kelas X.3 dengan jumlah siswa sebanyak 42 orang. Pemilihan kelas berdasarkan kesepakatan antara peneliti dan guru berdasarkan karakteristik peserta didik dan relevansinya dengan metode yang akan dilaksananakan serta tujuan penelitian. Teknik pengumpul data dilakukan dengan pengamatan observasi aktivitas belajar siswa selama pembelajaran berlangsung dan wawancara. Alat yang digunakan untk mengumpulkan data adalah Lembaran observasi dan pedoman wawancara. Lembar observasi pembelajaran yang dikembangkan bersama oleh peneliti dan guru.

Berdasarkan tujuan penelitian dan kajian teoretis maka aktivitas belajar yang difokuskan dalam penelitian ini adalah, 
Tabel 1 : Jenis Aktivitas Belajar yang Diamati

\begin{tabular}{|c|l|l|}
\hline No & \multicolumn{1}{|c|}{ Jenis Aktivitas } & \multicolumn{1}{c|}{ Keterangan } \\
\hline 1 & Aktivitas Individu & $\begin{array}{l}\text { Peserta didik mencoba mengerjakan tugas/soal } \\
\text { sendiri dengan penuh antusias }\end{array}$ \\
\hline 2 & Aktivitas Berpasangan & $\begin{array}{l}\text { Peserta didik tampak antusias mengerjakan } \\
\text { tugas/soal secara berpasangan }\end{array}$ \\
\hline 3 & Aktivitas Kelompok & Peserta didik terlihat aktif dalam kelompok \\
\hline 4 & $\begin{array}{l}\text { Aktivitas dalam bentuk } \\
\text { kepedulian terhadap diri } \\
\text { sendiri }\end{array}$ & $\begin{array}{l}\text { Peserta didik yang belum mampu mengerjakan } \\
\text { tugas/ soal akan bertanya kepada peserta didik } \\
\text { yang lain yang sudah mampu }\end{array}$ \\
\hline 5 & $\begin{array}{l}\text { Aktivitas dalam bentuk } \\
\text { kepedulian kepada teman }\end{array}$ & $\begin{array}{l}\text { Peserta didik yang sudah mampu mengerjakan } \\
\text { tugas/soal bersedia memberikan penjelasan } \\
\text { kepada peserta didik lain dengan catatan telah } \\
\text { diminta oleh peserta didik tersebut }\end{array}$ \\
\hline 6 & Aktivitas Antar Kelompok & $\begin{array}{l}\text { Peserta didik aktif dan antusias dalam } \\
\text { mengerjakan tugas/ soal baik sebagai Penanya } \\
\text { maupun Pemberi Penjelasan. }\end{array}$ \\
\hline
\end{tabular}

Sumber : Pengembangan oleh Peneliti

Untuk mengukur tingkat aktifitas siswa dalam pembelajaran maka indikator keberhasilan ditetapkan 80\%. Presentase ini mempedomani Sudjana (1996).

1. Apabila $\leq 51 \%$ siswa aktif masih perlu dilanjutkan dengan siklus berikutnya

2. Apabila $\geq 51 \%-80 \%$ siswa aktif perlu dikonfirmasikan dengan guru

3. Apabila $\geq 80 \%$ siswa aktif tindakan dianggap berhasil

HASIL DAN PEMBAHASAN
Berdasarkan tujuan penelitian yaitu untuk meningkatkan aktivitas belajar siswa yang meliputi aktivitas individu, aktivitas berpasangan, aktivitas dalam kelompok dan aktivitas klasikal dalam mengerjakan tugas/soal yang diberikan maka hasilnya adalah sebagai berikut.

\section{Pembelajaran Pertama}

Semua aktivitas belajar tersebut berlangsung pada kegiatan pembelajaran pada siklus 1 tanggal 26 September 2016, untuk lebih jelasnya dapat dilihat pada uraian berikut ini.

Tabel 2 : Aktivitas Belajar Siswa pada Pembelajaran/Siklus I

\begin{tabular}{|c|l|c|c|c|c|c|c|}
\hline \multirow{2}{*}{ No } & \multicolumn{1}{|c|}{ Jenis Aktivitas } & \multicolumn{5}{|c|}{ Observer dan $\%$ Aktivitas Belajar } \\
\cline { 4 - 8 } & & $\begin{array}{c}1 / \\
\%\end{array}$ & $2 / \%$ & $\begin{array}{c}3 / \\
\%\end{array}$ & $\begin{array}{c}4 / \\
\%\end{array}$ & $\begin{array}{c}5 / \\
\%\end{array}$ & Rata2 \\
\hline 1 & Aktivitas Individu & 100 & 100 & 100 & 100 & 100 & 100 \\
\hline 2 & Aktivitas Berpasangan & 92,10 & 89,47 & 89,47 & 92,10 & 94,73 & 91,57 \\
\hline 3 & Aktivitas Kelompok & 97,36 & 92,10 & 89,47 & 89,47 & 92,10 & 92,1 \\
\hline 4 & $\begin{array}{l}\text { Aktivitas dalam bentuk kepedulian terhadap } \\
\text { diri sendiri }\end{array}$ & 15,78 & $\begin{array}{l}21, \\
05\end{array}$ & 18,42 & 15,78 & 13,15 & 16,83 \\
\hline 5 & $\begin{array}{l}\text { Aktivitas dalam bentuk kepedulian kepada } \\
\text { teman }\end{array}$ & 15,78 & 21,05 & 18,42 & 15,78 & 13,15 & 16,83 \\
\hline 6 & Aktivitas Antar Kelompok & 7,89 & 7,89 & 7,89 & 7,89 & 7,89 & 7,89 \\
\hline
\end{tabular}

Sumber : Pengolahan Data Penelitian 2016

Berdasarkan tabel rekapitulasi aktivitas belajar pada siklus 1 di atas terlihat bahwa rata-rata observer mencatat $100 \%$ siswa menunjukkan aktivitas belajar 
individu..Namun, pada aktivitas belajar yang kedua yaitu aktivitas belajar berpasangan terlihat bahwa ternyata persentase siswa yang melakukannya tidak jauh berbeda dengan aktivitas individu. Artinya, hampir sebagian besar siswa ternyata tidak bisa mengerjakan tugas/soal secara individu maka guru meminta mereka bekerja berpasangan. Tercatat sebanyak 91,57 \% siswa tidak bisa mengerjakan tugas/soal secara individu sehingga mereka perlu berpasangan. Fakta menarik lainnya adalah jumlah anak yang menunjukkan aktivitas belajar berupa peduli pada diri sendiri justru berbanding terbalik dengan jumlah siswa yang tidak bisa mengerjakan tugas/soal sendiri. Logikanya jumlah siswa pada pada baris nomor 2 dan 4 seharusnya hampir sama. Artinya, siswa yang tidak bisa menjawab tugas/soal harus memiliki kepedulian terhadap dirinya berupa bertanya kepada siswa lain yang sudah berhasil. Tapi, kondisi ini bisa dimaklumi karena metode ini masih baru bagi mereka atau bisa juga karena belum terbiasa di kalangan siswa.Terkait dengan aktivitas kelompok, ada tujuh orang siswa yang berasal dari tujuh kelompok yang berbeda yang melakukan aktivitas antar kelompok dimana kelompok mereka belum mampu mengerjakan tugas/soal. Jika satu siswa mewakili empat siswa maka untuk soal jumping task maka ada 28 siswa yang belum bisa mengerjakannya dengan benar atau sekitar 73,68\%.

\section{Pembelajaran Kedua}

Tabel 3 : Aktifitas Belajar Siswa pada Pembelajaran/Siklus II

\begin{tabular}{|c|c|c|c|c|c|c|c|}
\hline \multirow{2}{*}{ No } & \multirow{2}{*}{ Jenis Aktivitas } & \multicolumn{6}{|c|}{ Observer dan \% Aktivitas Belajar } \\
\hline & & $1 / \%$ & $2 / \%$ & $3 / \%$ & $4 / \%$ & $5 / \%$ & Rata2 \\
\hline 1 & Aktivitas Individu & 100 & 100 & 100 & 100 & 100 & 100 \\
\hline 1.1 & Siswa yang belum bisa menjawab & 20 & 21 & 16 & 18 & 18 & 18,2 \\
\hline 2 & Aktivitas Berpasangan & $\begin{array}{l}45 \% \\
(18)\end{array}$ & $\begin{array}{l}52,5 \% \\
(21)\end{array}$ & $\begin{array}{l}42.5 \% \\
(17)\end{array}$ & $\begin{array}{l}45 \% \\
(18)\end{array}$ & $\begin{array}{l}45 \% \\
(18)\end{array}$ & $46 \%$ \\
\hline 3 & Aktivitas Kelompok & $90 \%$ & $87,5 \%$ & $90 \%$ & $92,5 \%$ & $92,5 \%$ & $90,5 \%$ \\
\hline 4 & $\begin{array}{l}\text { Aktivitas dalam bentuk kepedulian } \\
\text { terhadap diri sendiri }\end{array}$ & $\begin{array}{l}16 / 18 \\
88.88 \% \\
\end{array}$ & $\begin{array}{l}19 / 21 \\
90.47 \% \\
\end{array}$ & $\begin{array}{l}15 / 16 \\
93.75 \% \\
\end{array}$ & $\begin{array}{l}18 / 18 \\
100 \%\end{array}$ & $\begin{array}{l}18 / 18 \\
100 \%\end{array}$ & $94.62 \%$ \\
\hline 5 & $\begin{array}{l}\text { Aktivitas dalam bentuk kepedulian } \\
\text { kepada teman }\end{array}$ & $\begin{array}{l}16 / 18 \\
88.88 \%\end{array}$ & $\begin{array}{l}19 / 21 \\
90.47 \%\end{array}$ & $\begin{array}{l}15 / 16 \\
93.75 \%\end{array}$ & $\begin{array}{l}18 / 18 \\
100 \%\end{array}$ & $\begin{array}{l}18 / 18 \\
100 \%\end{array}$ & $94.62 \%$ \\
\hline 6 & Aktivitas Antar Kelompok & $40 \%$ & $40 \%$ & $40 \%$ & $40 \%$ & $40 \%$ & $40 \%$ \\
\hline 6.1 & $\begin{array}{llll}\begin{array}{l}\text { Kelompok yang } \\
\text { menjawab }\end{array} & & & \\
\end{array}$ & 6 & 6 & 6 & 6 & 6 & \\
\hline
\end{tabular}

Sumber : Pengolahan Data Penelitian 2016

Berdasarkan tabel rekapitulasi aktivitas belajar pada siklus 2 tanggal 10 Oktober 2016, terlihat bahwa rata-rata observer mencatat $100 \%$ siswa menunjukkan aktivitas belajar individu. Pada aktivitas belajar yang kedua yaitu aktivitas belajar berpasangan terlihat bahwa ternyata persentase siswa yang melakukannya menurun jauh jika dibandingkan dengan pembelajaran siklus 1. Jika pada siklus 1, aktivitas kedua ini mencapai 91,57\% maka pada pembelajaran siklus 2 tinggal $46 \%$.
Artinya, jumlah siswa yang belum bisa mengerjakan soal/tugas hanya tinggal sekitar 18 siswa dari 40 siswa. Dilihat dari aktivitas kepedulian terhadap diri sendiri, juga terjadi peningkatan yang cukup signifikan dimana $94,62 \%$ siswa peduli terhadap dirinya sendiri. Disini terdapat sedikit perbedaan atau lebih tepatnya penyempurnaan dari siklus 1 dimana persentase aktivitas kepedulian terhadap diri sendiri diambil dari jumlah siswa yang belum bisa menjawab soal/tugas yang diberikan sehingga hasilnya jauh 


\section{gé grafi}

lebih mewakili. Demikian juga aktivitas belajar berupa kepedulian terhadap teman juga memperlihatkan angka yang sama yang artinya semua siswa mau dengan sukarela membantu temannya yang belum mengerti tentang tugas/soal yang diberikan. Sedangkan pada pengerjaan soal secara berkelompok, sebanyak empat kelompok berhasil menjawab dengan benar dan ada enam kelompok yang belum berhasil dengan persentase
$40 \%$ dan $60 \%$. Kondisi ini juga membaik dimana terjadi peningkatan walaupun hanya bertambah satu kelompok saja dari tiga menjadi empat kelompok.

\section{Pembelajaran Ketiga/Siklus 3}

Semua aktivitas belajar tersebut berlangsung pada kegiatan pembelajaran pada siklus 3 dan siklus 3 tanggal 17 Oktober 2016. Untuk lebih jelasnya dapat dilihat pada uraian berikut ini.

Tabel 4. Aktifitas Belajar Siswa pada Pembelajaran/Siklus III

\begin{tabular}{|c|c|c|c|c|c|c|c|}
\hline \multirow{2}{*}{ No } & \multirow{2}{*}{ Jenis Aktivitas } & \multicolumn{6}{|c|}{ Observer dan \% Aktivitas Belajar } \\
\hline & & $1 / \%$ & $2 / \%$ & $3 / \%$ & $4 / \%$ & $5 / \%$ & Rata2 \\
\hline 1 & Aktivitas Individu & 100 & 100 & 100 & 100 & 100 & 100 \\
\hline 1.1 & $\begin{array}{lll}\text { Siswa yang belum bisa } \\
\text { menjawab }\end{array}$ & $\begin{array}{l}35 \% \\
(14)\end{array}$ & $\begin{array}{l}35 \% \\
(14)\end{array}$ & $\begin{array}{l}35 \% \\
(14)\end{array}$ & $\begin{array}{l}35 \% \\
(14)\end{array}$ & $\begin{array}{l}35 \% \\
(14)\end{array}$ & $35 \%$ \\
\hline 2 & Aktivitas Berpasangan & $100 \%$ & $100 \%$ & $100 \%$ & $100 \%$ & $100 \%$ & $100 \%$ \\
\hline 3 & Aktivitas Kelompok & $92.5 \%$ & $92.5 \%$ & $90 \%$ & $90 \%$ & $92.5 \%$ & $91.5 \%$ \\
\hline 4 & 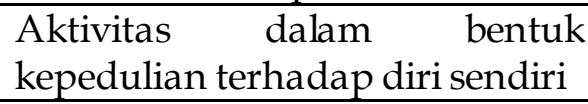 & $\begin{array}{l}13 / 14 \\
92.8 \% \\
\end{array}$ & $\begin{array}{l}12 / 14 \\
85.7 \%\end{array}$ & $\begin{array}{l}14 / 14 \\
100 \%\end{array}$ & $\begin{array}{l}13 / 14 \\
92.8 \% \\
\end{array}$ & $\begin{array}{l}14 / 14 \\
100 \%\end{array}$ & $94.26 \%$ \\
\hline 5 & $\begin{array}{l}\text { Aktivitas dalam bentuk } \\
\text { kepedulian kepada teman }\end{array}$ & $\begin{array}{l}13 / 14 \\
92.85 \\
\%\end{array}$ & $\begin{array}{l}12 / 14 \\
85.71 \%\end{array}$ & $\begin{array}{l}14 / 14 \\
100 \%\end{array}$ & $\begin{array}{l}13 / 14 \\
92.85 \%\end{array}$ & $\begin{array}{l}14 / 14 \\
100 \%\end{array}$ & $94.28 \%$ \\
\hline 6 & Aktivitas Antar Kelompok & $40 \%$ & $40 \%$ & $40 \%$ & $40 \%$ & $40 \%$ & $40 \%$ \\
\hline 6.1 & $\begin{array}{llll}\text { Kelompok yang belum bisa } \\
\text { menjawab }\end{array}$ & 6 & 6 & 6 & 6 & 6 & \\
\hline
\end{tabular}

Sumber : Pengolahan Data Penelitian 2016

Berdasarkan tabel rekapitulasi aktivitas belajar pada siklus 3 di atas terlihat bahwa rata-rata observer mencatat 100\% siswa menunjukkan aktivitas belajar individu. Pada aktivitas belajar yang kedua yaitu aktivitas belajar berpasangan terlihat bahwa ternyata persentase siswa yang melakukannya menurun jauh jika dibandingkan dengan pembelajaran siklus 2. Jika pada siklus 2, aktivitas kedua ini mencapai $46 \%$ maka pada pembelajaran siklus 3 tinggal 35\%. Artinya, jumlah siswa yang belum bisa mengerjakan soal/tugas hanya tinggal sekitar 14 siswa dari 40 siswa. Dilihat dari aktivitas kepedulian terhadap diri sendiri, terlihat hampir sama dengan siklus 2. Tidak ada peningkatan dan penurunan secara signifikan dengan dengan siklus 3 yaitu $94,26 \%$ siswa peduli terhadap dirinya sendiri. Demikian juga aktivitas belajar berupa kepedulian terhadap teman juga memperlihatkan angka yang sama yang artinya semua siswa mau dengan sukarela membantu temannya yang belum mengerti tentang tugas/soal yang diberikan.

Melihat hasil pelaksanaan penelitian di atas maka dapat dirangkum perkembangan aktivitas belajar siswa dalam pembelajaran dengan menerapkan metode "Jumping Task" sebagai berikut. 
Tabel 5 : Rekapitulasi Aktivitas Belajar Siklus I,II dan III

\begin{tabular}{|c|l|c|c|c|}
\hline \multirow{2}{*}{ No Jenis Aktivitas } & \multicolumn{3}{|c|}{ Rata-Rata } & \multicolumn{2}{|c|}{ Aktivitas Belajar (\%) Siklus I, } \\
\cline { 3 - 5 } & & Siklus I & Siklus II & Siklus III \\
\hline 1 & Aktivitas Individu & 100 & 100 & 100 \\
\hline 2 & Aktivitas Berpasangan & 91,57 & 46 & 100 \\
\hline 3 & Aktivitas Kelompok & 92.1 & 90,5 & 91.5 \\
\hline 4 & $\begin{array}{l}\text { Aktivitas dalam bentuk kepedulian terhadap } \\
\text { diri sendiri }\end{array}$ & 16.83 & 94.62 & 94.26 \\
\hline 5 & $\begin{array}{l}\text { Aktivitas dalam bentuk kepedulian kepada } \\
\text { teman }\end{array}$ & 16.83 & 94.62 & 94.26 \\
\hline 6 & Aktivitas Antar Kelompok & 7.89 & 40 & 40 \\
\hline
\end{tabular}

Sumber : Pengolahan Data Penelitian 2016

Tabel di atas memperlihatkan bahwa:

1. Untuk aktivitas individu, pada tiga kali pembelajaran, semua siswa terlibat dengan aktif. Artinya, siswa mencoba mengerjakan soal/tugas yang diberikan.

2. Untuk aktivitas berpasangan, dalam tiga kali pembelajaran terdapat perkembangan yang fluktuatif yaitu dari angka 91,57, lalu menjadi 46 dan terakhir meningkat menjadi $100 \%$. Artinya bahwa peserta didik membuka diri untuk bekerja sama dan berdialog dengan temannya.

3. Untuk aktivitas kelompok, perkembangan aktivitas belajar mulai dari 92,1 \%, lalu turun sedikit menjadi 90,5\% lalu naik lagi menjadi $91,5 \%$.

4. Untuk aktivitas berupa kepedulian terhadap diri sendiri juga menunjukkan angka yang menarik yaitu mulai dari 16, 83\%, lalu meningkat tajam mencapai 94,62 \% pada siklus berikutnya.

5. Untuk aktivitas dalam bentuk kepedulian kepada teman juga memperlihatkan tren yang sama yaitu mulai dari 16,83\%, lalu menjadi $94,26 \%$ pada dua kali pembelajaran berikutnya.

6. Untuk aktivitas antar kelompok meningkat dari 7,89 menjadi $40 \%$. Khusus untuk aktivitas ini, capaian persentase dimaknai dalam dua hal. Pertama, jika angka capaian kecil bisa diartikan bahwa kelompok bisa menyelesaikan tugas/soal yang diberikan sehingga tidak perlu melakukan aktivitas antar kelompok. Kedua, angka capaian kecil bisa berarti bahwa guru gagal dalam merangsang siswa untuk bertanya atau mencari informasi ke kelompok lain jika tidak bisa menyelesaikannya dalam kelompok. Untuk penelitian yang telah dilakukan, angka yang terlihat mengacu kepada kondisi pertama.

Peningkatan aktivitas belajar siswa dalam pembelajaran semata-mata ditujukan untuk mencapai tujuan-tujuan pembelajaran. Namun, tujuan pembelajaran disini tidak hanya sebatas pada penguasaan materi saja. Penerapan metode "jumping task" pada pembelajaran geografi sebanyak tiga kali siklus di SMA Islam Al Istiqamah memperlihatkan bahwa pemberian soal/tugas kategori "Jumping Task" mampu meningkatkan aktivitas belajar siswa baik aktivitas individu, aktivitas berpasangan, aktivitas dalam kelompok dan aktivitas klasikal. Berhubung, dalam penelitian ini dan dalam setiap pembelajaran semua soal/tugas sudah dibahas tuntas maka tercapai tidaknya tujuan penelitian dilihat dari persentase aktivitas belajar yang ditunjukkan siswa. 
Merujuk pada kategori yang dikemukakan Sudjana (1999) maka pembelajaran dikatakan berhasil jika aktivitas belajar mencapai lebih dari $80 \%$. Berdasarkan hasil penelitian, untuk semua aktivitas belajar dalam tiga kali pelaksanaan sudah melewati angka tersebut dengan arti penerapan metode "jumping task" sudah berhasil.

Terkait dengan hal tersebut dan melihat hubungannya dengan aspek refleksi dalam penelitian ini, berhasil atau tidaknya suatu metode pembelajaran sangat ditentukan oleh kesiapan guru dan kemampuan guru mengelola kelas. Tugas guru tidak lagi sebagai pemberi pengetahuan dan pola-pola lama (ceramah) atau "spoon feeding", tapi sebagai penyedia ruang dan fasilitas bagi siswa untuk belajar. Salah satu cara untuk membelajarkan siswa adalah dengan memberikan soal/tugas yang menantang yang disebut dalam penelitian ini dengan istilah "jumping task". Soal - soal yang sulit bukan berarti akan membunuh kemampuan siswa, namun dengan pengelolaan yang baik, soal-soal yang sulit atau menantang akan merangsang terciptanya dialog, interaksi dan kolaborasi antara peserta didik. Sehingga aktivitas belajar lebih bermakna. Inilah makna reformasi kelas yang dikemukakan oleh Manabu Sato yang disebut dengan reformasi kelas yang fokus pada aktivitas belajar berupa terciptanya dialog, interaksi dan kolaborasi di antara peserta didik (Sato, 2013:21-34).

Penataan atau pengelolaan polapola dialog, interaksi dan kolaborasi antar peserta didik juga penting dilakukan agar setiap siswa dapat mencapai puncak optimum kemampuan belajar yang disebut oleh Lev Vygotsky dengan konsep Zone of Proximal Development/ZPD dimana hal itu bisa dicapai dengan adanya bantuan atau interaksi dengan orang lain. Orang lain disini bisa saja guru atau teman sebaya. Jika dalam satu kali pembelajaran tercipta dialog, interaksi dan kolaborasi baik antara peserta didik dengan peserta didik lain, maupun dengan pendidik maka pembelajaran tersebut sudah mengejawantahkan amanat Undang-undang Nomor 20 tahun 2003 tentang Sistem Pendidikan Nasional, khususnya Pasal 1 Ayat 20 yang menyatakan bahwa pembelajaran adalah proses interaksi peserta didik dengan pendidik dan sumber belajar pada suatu lingkungan belajar.

\section{PENUTUP}

Penerapan metode "Jumping Task" yang dalam penelitian ini diartikan sebagai pembelajaran yang ditandai dengan pemberian soal-soal yang sulit dan menantang kepada siswa terbukti mampu meningkatkan aktivitas belajar siswa. Aktivitas belajar yang berhasil ditingkatkan adalah aktivitas belajar individu, aktivitas belajar berpasangan, aktivitas belajar dalam kelompok dan aktivitas belajar klasikal. Pembelajaran yang efektif adalah pembelajaran yang tidak hanya fokus pada kemampuan kognitif saja, namun juga memberikan ruang untuk terciptanya saling peduli dan kolaborasi antar peserta didik melalui penataan atau pengelolaan pola-pola dialog, interaksi dan kolaborasi di dalam kelas. Metode "Jumping Task" ini diharapkan mampu mendukung implementasi pembelajaran berdasarkan Kurikulum 2013 dimana tercipta pengembangan aspek pengetahuan dan keterampilan serta pengembangan sikap spiritual dan sosial secara proporsional.

\section{DAFTAR PUSTAKA}

Ahmad, Abu. 2002. Pengelolaan Pengajaran. Jakarta,PT. Rineka Cipta

Djamarah. 2002. Proses Belajar Mengajar. Bandung, PT. Tarsito

Johnson, D. W., Johnson, R. T., \& Smith, K. A. (1991). Active Learning: Cooperation In The College Classroom. Interaction Book Co. Edina, MN 
Permendikbud nomor 22 tahun 2016 tentang Standar Proses Pendidikan Dasar dan Menengah

Pribadi A. Benny. 2009. Model Desain Sistem Pembelajaran. Jakarta. Penerbit Dian Rakyat

Sato, Manabu. 2012. Mereformasi Sekolah. Jakarta. PELITA/JICA

Sato, Masaaki. 2012. Dialog dan Kolaborasi di Sekolah Menengah Pertama. Praktek "Learning Community". Jakarta. PELITA/JICA

Sudjana. 1996. Metode Statistik, Bandung: PT. Tarsito

Undang-undang Nomor 20 Tahun 2003 Tentang Sistem Pendidikan Nasional 